\title{
Can We Talk? The Application of the Public Law Democratic Dialogue Model to the Interactions between Domestic Legislatures and the European Courts
}

\author{
Matilda Gillis ${ }^{1}$ \\ ${ }^{1}$ Peterhouse, University of Cambridge, Cambridge, United Kingdom \\ Corresponding author: meg55@cam.ac.uk
}

(Received 03 March 2021; accepted 29 April 2021)

\begin{abstract}
The democratic dialogue model is a domestic constitutional model of rights protection, which is used to explain and evaluate the relationship between domestic courts and legislatures. It is characterised by there being some capacity on the part of the legislature to respond to a court decision and it claims, among other things, to produce a 'better protection of human rights'. This paper examines whether the democratic dialogue model can be, and should be, applied to the relationship between state legislatures and, respectively, the European Court of Human Rights and the Court of Justice of the European Union (the European Courts). The paper first demonstrates that this proposed application of the model differs from other accounts of dialogue hitherto applied at the transnational level. It examines how exactly the model can be applied to the relationship between national legislatures and the European Courts and it demonstrates that the model provides an explanatory framework for the interactions between the institutions. It argues that the normative claims of the domestic dialogue model are achieved when the model is applied in the proposed way, but it acknowledges that the achievement of those normative claims might not always be desirable at the transnational level.
\end{abstract}

Keywords: Democratic dialogue; human rights law; transnational law; European Court of Human Rights; Court of Justice of the European Union

\section{A. Introduction}

'Always get to the dialogue as soon as possible. I always feel the thing to go for is speed. Nothing puts the reader off more than a big slab of prose at the start'.

The purpose of this article is to examine whether the domestic law model of democratic dialogue can be, and should be, applied to the relationship between state legislatures and, respectively, the European Court of Human Rights (ECtHR) and the Court of Justice of the European Union

I am very grateful to Professor Alison Young and Dr. Andrew Sanger for their extremely helpful comments and guidance on an earlier version of this paper.

${ }^{1} \mathrm{PG}$ Wodehouse, cited in Sam Jordison, PG Wodehouse's creative writing lessons, ThE GuARdian (May 7, 2014), https:// www.theguardian.com/books/booksblog/2014/may/07/pg-wodehouse-creative-writing-leave-it-to-psmith-reading-group (last visited Nov 7, 2019).

(C) The Author(s) 2022. Published by Cambridge University Press on behalf of the German Law Journal. This is an Open Access article, distributed under the terms of the Creative Commons Attribution licence (https://creativecommons.org/licenses/by/4.0/), which permits unrestricted re-use, distribution, and reproduction in any medium, provided the original work is properly cited. 
(CJEU) (collectively, the European Courts). The model is, in general terms, a constitutional model of rights protection, which is used to explain and evaluate the relationship between domestic courts and domestic legislatures. It is characterized by there being some capacity on the part of the legislature to respond to a court decision, and its promise is, among other things, to produce a "better protection of human rights" in the sense of providing both a political and legal protection of rights. ${ }^{2}$ This paper ultimately argues that, while there are some instances where it may be normatively advantageous for international courts and, specifically, the European Courts, to have "the last word," there is utility in applying the dialogue model in the way proposed, as the model's claimed normative advantages are achieved when applied to the interactions between domestic legislatures and the European Courts. This argument is built in three stages.

Part B is foundational. It sets out what is meant by "dialogue" and the dialogue model at domestic law, and it examines the model's descriptive and normative dimensions. It considers what is meant by the use of those and similar terms in the international law sphere generally, before distinguishing those accounts of dialogue from the public law dialogue model to be applied here. Part $\mathrm{C}$ examines precisely how the public law dialogue model might be applied to the relationship between domestic legislatures and the ECtHR and to the relationship between domestic legislatures and the CJEU. Part D explores why the application of the public law dialogue model in the way hitherto suggested might be useful.

\section{B. Accounts of Dialogue}

\section{Accounts of Dialogue at Public Law}

"Dialogue" can mean different things. The term may connote a simple conversation, the value of which "resides primarily in the exchange itself rather than in some other purpose, aim, or end," or it may mean, more precisely, a discussion between equal partners with the specific aim and purpose of reaching a collective decision. ${ }^{3}$

At domestic public law, the word "dialogue" operates as a metaphor to explain, generally speaking, particular interactions that occur between legislatures and judiciaries. Where such interactions take place or have the potential to take place, the word "dialogue" also functions to describe the relationship between those institutions.

Christine Bateup provides a comprehensive overview of the interactions between legislatures and judiciaries that have been labelled "dialogue." She distinguishes broadly between how courts interact with the political branches to resolve constitutional problems via: (i) "judicial decisionmaking techniques," such as the application of interpretive criteria, "process-centred rules" and a doctrine of "judicial minimalism" 4 and (ii) institutional mechanisms and processes. ${ }^{5}$ While the two conceptions of dialogue are connected and inform each other, it is the latter with which this paper is particularly concerned and to which it refers as "institutional dialogue."

While there are various theories of "institutional dialogue" and differing views as to what actually constitutes "dialogue," most accounts begin with Peter Hogg and Allison Bushell's 1997 study. ${ }^{6}$ Hogg and Bushell examined instances in which the Supreme Court of Canada struck

\footnotetext{
${ }^{2}$ Alison L. Young, Democratic Dialogue and the Constitution 11 (1st ed. 2017).

${ }^{3}$ Grégoire C. N. Webber, The Unfulfilled Potential of the Court and Legislature Dialogue, 42 CANAdian J. POL. SCI./REvUE CANADIENNE DE SCIENCE POLITIQUE 443, 450-51 (2009).

${ }^{4}$ Christine Bateup, The Dialogic Promise: Assessing the Normative Potential of Theories of Constitutional Dialogue, 71 BROOK. L. REV. 1109, 1123-24, 1128-29, 1131-32 (2006).

${ }^{5} I d$. at 1136 .

${ }^{6}$ Peter W. Hogg \& Allison A. Bushell, The Charter Dialogue Between Courts and Legislatures, The (Or Perhaps the Charter of Rights Isn't Such a Bad Thing after All), 35 Osgoode HALL L. J. 75 (1997); See also Young, supra note 3; Webber, supra note 4; Rosalind Dixon, Creating Dialogue about Socioeconomic Rights: Strong-Form versus Weak-Form Judicial Review Revisited, 5 InT'L J. Const. L. 391 (2007); Bateup, supra note 5; Emmett Macfarlane, Dialogue or Compliance? Measuring Legislatures' Policy Responses to Court Rulings on Rights, 34 InT'L PoL. SCI. Rev. 39 (2012); Mark V. Tushnet, New Forms of Judicial Review
} 
down legislation on the basis of its incompatibility with the Canadian Charter of Fundamental Rights and Freedoms, ${ }^{7}$ and in which the Canadian legislature subsequently took some action in light of, and in response to, the court decision, such as, for example, by amending or repealing the relevant legislation or explicitly ignoring the decision. ${ }^{8}$ Hogg and Bushell called these interactions "dialogue" and described the process as follows:

[Whenever] a judicial decision is open to legislative reversal, modification, or avoidance, then it is meaningful to regard the relationship between the Court and the competent legislative body as a dialogue... [T] he legislative body is in a position to devise a response that is properly respectful of the Charter values that have been identified by the Court, but which accomplishes the social or economic objectives that the judicial decision has impeded. ${ }^{9}$

In 2007, Hogg, Bushell and Wright further clarified their analysis:

[T]he legislature and the executive may act on their interpretation of the Charter... However, where the interpretive task takes place against the backdrop of a prior relevant judicial decision, the legislature and the executive may not act on an interpretation of the Charter which conflicts with an interpretation provided by the Courts. ${ }^{10}$

Hogg and Bushell identified four mechanisms in the Canadian Charter which facilitate legislative response to judicial decisions and which, accordingly, support the Canadian Charter being described as providing a dialogic model of human rights protection. Those institutional mechanisms are: (i) section 33 of the Canadian Charter, which provides the legislature with an override power, allowing the legislature to re-enact legislation without judicial interference; ${ }^{11}$ (ii) section 1 , which provides that Canadian Charter rights can be subject to "reasonable limits prescribed by law as can be demonstrably justified in a free and democratic society"; 12 (iii) "qualified rights" in, for example, sections 7, 8, 9 and 12 of the Canadian Charter, which provide for limitations of the right where, for example, the limitation is fair or reasonable or not arbitrary; ${ }^{13}$ (iv) section 15 of the Canadian Charter, which guarantees equality rights and provides that Charter rights can be satisfied "through a variety of remedial measures'. ${ }^{14}$

and the Persistence of Rights- and Democracy-Based Worries, 38 WAKE FOREST L. ReV. 813 (2003); Miguel Schor, Constitutional Dialogue and Judicial Supremacy, in Comparative Constitutional Theory 86 (Gary Jacobsohn \& Miguel Schor eds., 2018). Even those accounts that disagree with Hogg and Bushell's definition of dialogue usually begin with this account. Tremblay, for example, argues that any definition of dialogue requires the reaching for a common goal: Luc B. Tremblay, The Legitimacy of Judicial Review: The Limits of Dialogue Between Courts and Legislatures, 3 INT'L J. CONST. L. 617 (2005). Manfredi and Kelly, the most prominent critics of Hogg and Bushell's study, also begin this way. In their view only "negative responses" or those responses that show some disagreement with the court decision on the part of the legislature are "dialogue" and that where legislatures simply agree with the judicial decision this creates a "hierarchical relationship between courts and legislatures, rather than a relationship of equality necessary for true dialogue': Christopher P. Manfredi \& James B. Kelly, Six Degrees of Dialogue: A Response to Hogg and Bushell Forum, 37 Osgoode HALL L. J. 513 (1999).

${ }^{7}$ See Part B of the Constitution Act, 1982, being Schedule B to the Canada Act, 1982, C 11 (U.K).

${ }^{8}$ Hogg \& Bushell, supra note 7 , at 82 .

${ }^{9} I d$.; Bateup usefully describes how this interaction might typically occur, see Bateup, supra note 5, at 1109 (2006). See also Kent Roach, Dialogic Judicial Review and its Critics, 23 Sup. CT. L. REV. 49 (2004); Rosalind Dixon, The Supreme Court of Canada, Charter Dialogue, and Deference, 47 Osgoode Hall L.J. 235 (2009).

${ }^{10}$ Peter M. Hogg, et al., Charter Dialogue Revisited: Or Much Ado about Metaphors Charter Dialogue: Ten Years Later, 45 Osgoode HaLl L.J. 1, 33 (2007).

${ }^{11}$ Hogg \& Bushell, supra note 7 , at 83 .

${ }^{12} I d$. at 84 .

${ }^{13} I d$. at $87-88$.

${ }^{14} I d$. at 90 . 
Mechanisms that facilitate a legislative response to court decisions, or as Jackson describes it more fully, mechanisms that provide for "some capacity for judicial review of legislation whilst preserving parliamentary sovereignty and enhancing Parliament's role in human rights protection," ${ }^{15}$ have subsequently been identified in various systems, such as in Australia, ${ }^{16} \mathrm{New}$ Zealand, ${ }^{17}$ the United Kingdom, ${ }^{18}$ and, albeit to a lesser extent, in the United States. ${ }^{19}$ The relationship between the legislatures and judiciaries in these systems has, accordingly, been described as being one of dialogue.

Alison Young examines these various systems and investigates the similarities and differences among the mechanisms and processes and what it is about them that gives rise to relationships of dialogue between constitutional institutions. She finds that there are no necessary or sufficient criteria that need to be met to facilitate dialogue. ${ }^{20}$ Rather, dialogue, according to Young, is facilitated through various and diverse institutional mechanisms, features and structures, ${ }^{21}$ which, broadly speaking, fit within two groups: (i) those that give rise to "constitutional collaboration" and (ii) those that give rise to "constitutional counter-balancing."

Mechanisms that give rise to "constitutional collaboration" are those that "enable the legislature and the judiciary to work together drawing on their relative strengths and weaknesses when reasoning about rights." ${ }^{22}$ These mechanisms allow each institution "to take account not just of reasons for and against a particular resolution of rights issues, but also other reasons which would require each institution to give weight to the resolution of the other." ${ }^{23}$ Mechanisms that give rise to constitutional counter-balancing are those that "ensure that both the legislature and the judiciary play a role in the determination of rights issues, whilst ensuring that it is not the case that one institution is always able to authoritatively determine the issues, effectively overriding the contribution of the other." ${ }^{24}$ As Jeff King notes, for "dialogue," there must be "a relationship of approximate equality between courts and legislatures." ${ }^{25}$ Mechanisms of constitutional counter-balancing must be used rarely, however, if they are to facilitate dialogue. ${ }^{26}$

Hogg and Bushell argued that the legislature's ability to respond to court decisions in a manner which accomplished its own objectives, demonstrated that "judicial review under the Charter was weaker than is generally supposed" and "greatly diminished" arguments that the Charter is undemocratic. ${ }^{27}$ Hogg and Bushell, however, emphasized that they were not drawing normative conclusions as to whether judicial review is either good or bad. ${ }^{28}$ Despite this, dialogue theorists

\footnotetext{
${ }^{15}$ Sara Jackson, Designing Human Rights Legislation: Dialogue, the Commonwealth Model and the Roles of Parliaments and Courts, 13 Auckland U. L. Rev. 89, 89 (2007).

${ }^{16}$ These mechanisms have been identified in only some Australian jurisdictions, such as in Victoria and the Australian Capital Territory. See, e.g., Scott Stephenson, Constitutional Reengineering: Dialogue's Migration from Canada to Australia, 11 InT'L J. Const. L. 870 (2013); Leighton McDonald, Rights, 'Dialogue' and Democratic Objections to Judicial Review, 32 FED. L. REV. 1 (2004).

${ }^{17}$ See, e.g., Andrew Geddis, Inter-institutional 'Rights Dialogue' under the New Zealand Bill of Rights Act, in THE LEGAL Protection of Human Rights: Sceptical Essays 87 (Tom Campbell et al. eds., 2011); Léonid Sirota, Constitutional Dialogue: The New Zealand Bill of Rights Act and the Noble Dream, 27 N.Z. UnIvs. L. REv. 897 (2017).

${ }^{18}$ T. R. S. Allan, Constitutional Dialogue and the Justification of Judicial Review, 23 OXFORD J. LEGAL STUD. 563 (2003); Alison L. Young, Deference, Dialogue and the Search for Legitimacy, 30 OXFord J. LeGAL STUD. 815 (2010).

${ }^{19}$ See, e.g., Bateup, supra note 5; Barry Friedman, Dialogue and Judicial Review, 91 MicH. L. REV. 577, 653 (1992).

${ }^{20}$ Young, supra note 3, at 22.

${ }^{21} I d$. at $31,174-75$.

${ }^{22} I d$. at 33; Jackson, supra note 16 , at 92.

${ }^{23}$ Young, supra note 3, at 33. See also Bateup, supra note 5, at 1175.

${ }^{24}$ YounG, supra note 3, at 32-33.

${ }^{25}$ Jeff King, Dialogue, Finality and Legality, in Constitutional Dialogue: Rights, Democracy, Institutions 186-89 (Geoffrey Sigalet et al. eds., 2019).

${ }^{26}$ YounG, supra note 3, at 268.

${ }^{27}$ Hogg \& Bushell, supra note 7, at 80; Hogg, et al., supra note 11, at 29.

${ }^{28}$ Hogg \& Bushell, supra note 7, at 105.
} 
have since argued that the dialogue model not only provides an explanatory framework for how the judiciary and legislature interact on rights issues, but that dialogue is also normatively justified.

The idea that "dialogue" is normatively justified is not new. As Tremblay describes it:

[t]he idea that some form of dialogue, discussion, communication, deliberation, or discourse may confer legitimating force on political authority and decision making has been a recurrent theme in contemporary legal, political, and social philosophy. ${ }^{29}$

A dialogue between two equal partners is, more or less, the understanding of discourse on which Habermas bases his theory of deliberative democracy. ${ }^{30}$ What makes the normative justifications for the public law dialogue model somewhat unique and different from those normative theories of dialogue in philosophy and sociology, however, is the fact that the model is grounded in practice and in reality. As Young describes it, the public law dialogue model "rests on real facts and assumptions," but also provides an "aspirational ideal." 31

The key normative argument for the application of the dialogue model at public law is that it provides a "better protection of rights." 32 What is meant by this is not that the outcome is necessarily "better," but that the model allows for both a political and legal protection of rights. Most significantly, it does so in such a way that "maximises the advantages and minimises the dangers of purely legal or purely political protections of human rights" by providing a balance between or a "hybrid" of the two systems. ${ }^{33}$

Stephen Gardbaum and Young unpack this key claim further. They argue that the normative claim is achieved not simply because the dialogue model provides a balance between a purely legal or political protection of rights, but because it in fact provides a way to draw on the strengths of how courts and political branches reason about rights. The model draws on accounts of both legal and political constitutionalism. ${ }^{34}$ On the one hand, as Young notes, those who argue for a "strong legal protection of human rights rely on arguments similar to those underpinning legal constitutionalism." 35 Those arguments usually contend that the judiciary is the best placed institution to decide on rights because of that institution's independent nature, it being a "forum of principle," 36 and its focus on individual and minority interests as opposed to the "tyranny of the majority," which is represented by the legislature. ${ }^{37}$ The dialogue model allows the judiciary to function in this way.

On the other hand, those who argue for a political protection of rights rely on arguments similar to political constitutionalism. Those arguments contend that the political branch is best placed to decide on rights issues because the legislature is, unlike the un-elected judiciary, democratically representative and accountable, ${ }^{38}$ can balance competing groups and interests, ${ }^{39}$ and can deal with

\footnotetext{
${ }^{29}$ Tremblay, supra note 7, at 618. See, e.g., JÜrgen Habermas, Moral Consciousness and Communicative ACTION (Christian Lenhardt \& Shierry Weber Nicholsen trans., 2018); Bruce Ackerman, Why Dialogue?, 86 J. PHIL. 5 (1989); Jens Steffek, The Legitimation of International Governance: A Discourse Approach, 9 EUR. J. InT'L Rels. 249,271 (2003).

${ }^{30}$ See, e.g., Jürgen Habermas, Three Normative Models of Democracy, 1 ConstelLATIONS 1 (1994); Webber, supra note 4, at $450-51$.

${ }^{31}$ YOUNG, supra note 3, at 174 .

${ }^{32} I d$. at 31 .

${ }^{33} I d$. at 4, 148-52. See also Stephen Gardbaum, The New Commonwealth Model of Constitutionalism: Theory and Practice 51-61 (2013); Tom Hickman, Public Law after the Human Rights Act 71-80 (2010); Macfarlane, supra note 7, at 39; Jeffrey Goldsworthy, Homogenizing Constitutions, 23 OxFORD J. LEGAL STUD. 483 (2003).

${ }^{34}$ YounG, supra note 3, at 6, 32, 148-49; GARDBAUM, supra note 34.

${ }^{35}$ Young, supra note 3 , at 7.

${ }^{36}$ Webber, supra note 4, at 444; Kent RoACH, The Supreme COURT ON TRIAL: JUdicial aCtivism OR DEMOCRATIC DIALOGUE 285 (rev. ed. 2016).

${ }^{37}$ Webber, supra note 4, at 444; GARDBAUM, supra note 34; Cf., Bateup, supra note 5; Young, supra note 3, at 148.

${ }^{38}$ Tremblay, supra note 7, at 619; Young, supra note 3, at 148.

${ }^{39}$ Young, supra note 3, at 148.
} 
various and diverse issues in light of its particular "fact-fathering capabilities and specialised policy expertise." 40 The dialogue model also allows the legislature to function in this way. Accordingly, the model allows for the legislature and the judiciary to operate in such a way that reflects both institutions' relative strengths when reasoning about rights and thus, when the institutions work together, a "better protection of rights" is produced. ${ }^{41}$

There are additional normative advantages to the dialogue model alongside this claim. It is argued that the application of the public law dialogue model can, for example, lead to greater deliberation not only in the legislature and courts, but also in the wider community. When rights issues are openly discussed by institutions in public fora, more individuals and groups are able to contribute, either directly or indirectly, to the debate at hand..$^{42}$ Jean Leclair's study of Canadian dialogue, for instance, found that dialogue between Canadian courts and legislatures promotes and produces public debate about Canadian Charter values. ${ }^{43}$ The presence of more people involved in the discussion allows, in turn, for the introduction of "new ideas, perspectives, or even equilibriums into the political process," ${ }^{4}$ and greater "engagement with outside arguments." ${ }^{4}$ As Hiebert notes, the dialogue model "has the potential to encourage critical reflection on the merits of legislation from a broader spectrum of institutional actors than is normally associated with a bill of rights." 46

Young also suggests that the dialogue model at public law can produce "an effective set of checks and balances" between and among the constitutional institutions, ${ }^{47}$ and Jackson similarly notes that dialogue between the institutions can "be viewed as a mechanism providing a system of accountability and checks and balances." 48 The dialogue model, in effect, sets up a system of review as it allows the court to review decisions made by the political branches and, in turn, for the political branches to review the actions and decisions taken by the judiciary. ${ }^{49}$

Young argues that these normative claims of the model are most persuasive and have the greatest impact in the area of contestable rights issues. ${ }^{50}$ The extent to which the normative advantages of the dialogue model are achieved, however, depends on the particular constitutional system, and in turn, the particular dialogue model and mechanisms at play. As Jackson notes, the "quality of the 'dialogue' is conditioned upon the precise configuration of human rights instruments, and the mechanisms they establish to protect rights." ${ }^{1}$

\section{Accounts of Dialogue at the International or "Transnational" Level}

The metaphor of dialogue has also been used to explain interactions and relationships between and among various institutions at the international law, or what might more accurately be described as the "transnational law" sphere. "Transnational law" is, generally speaking, "all law which regulates actions or events that transcend national frontiers. Both public and private

\footnotetext{
${ }^{40}$ Bateup, supra note 5 , at $1176-77$.

${ }^{41}$ YounG, supra note 3, at 32-33, 150; GARDBAUM, supra note 34, at 61-76.

${ }^{42}$ Young, supra note 3 , at $31,154$.

${ }^{43}$ Jean Leclair, Judicial Review in Canadian Constitutional Law: A Brief Overview, 36 GeO WASH. InT'L. L. REv. 543, 458 (2004).

${ }^{44}$ Dixon, supra note 7 , at 407.

${ }^{45}$ Kent Roach, Constitutional, Remedial, and International Dialogues about Rights: The Canadian Experience Symposium: Globalization and the Judiciary, 40 TEx. INT'L L.J. 537-76, 550 (2004).

${ }^{46}$ See, e.g., Janet L. Hiebert, New Constitutional Ideas: Can New Parliamentary Models Resist Judicial Dominance When Interpreting Rights Symposium: Comparative Avenues in Constitutional Law - Innovative Models of Constitutionalism, 82 TEX. L. REV. 1963-88 (2003).

${ }^{47}$ Young, supra note 3, at 31 .

${ }^{48}$ Jackson, supra note 16, at 114. See also Vriend v. Alberta, [1998] S.C.R. 493 (Can.).

${ }^{49}$ Jackson, supra note 16, at 114.

${ }^{50}$ Young, supra note 3, at 11 .

${ }^{51}$ Jackson, supra note 16 , at 115; Dixon, supra note 7 , at 413 .
} 
international are included, as are other rules which do not wholly fit into such standard categories." 52

Devika Hovell, for example, describes the relationship between domestic courts and the United Nations Security Council as being one of "dialogue." 53 She argues that it would be misleading to describe the relationship between the institutions as "hierarchical" and characterized by binding law or supremacy, whereby domestic courts are viewed as subservient vis-à-vis the Security Council. This argument is based on what Hovell describes as the "enhanced power of domestic courts" and the position of domestic courts as persuasive authorities on and sources of, as opposed to enforcers of, international law. ${ }^{54}$ Although Security Council decisions are usually considered to be binding on states, domestic courts, Hovell shows, in fact have a choice in how to respond to resolutions on the part of the Security Council. Domestic courts can choose "either to interpret Security Council resolutions consistently with fundamental human rights principles, or to declare such resolutions inconsistent with human rights principles." 55 These "interpretive" and "declaratory" contributions, however, remain subject to the Security Council's response or repudiation. ${ }^{56}$

Roach, in contradistinction to Hovell, uses the term "dialogue" to describe the relationship between the UN Human Rights Committee (HRC) and Canadian Courts. ${ }^{57}$ He gives the interaction between these institutions the label "dialogue" on the basis that the HRC recites "the facts as submitted by the author of the complaint, submissions by the state's party, and responses to the submissions by the two parties," and thereby listens to the domestic courts before giving its own reasons on the matter. ${ }^{58}$ Like a conversation, Canada must then in turn "report back on the steps taken to respond to the decision." 59 The HRC must rely on governments' good faith and good will because its decisions and communications are not decisive or binding at domestic law. ${ }^{60}$

The most common theories of institutional dialogue in the international sphere have, however, developed in relation to interactions between and among courts. These accounts are various and diverse, but Anne-Marie Slaughter is the most prominent theorist in this respect and, like Hogg and Bushell for public law dialogue, most accounts of dialogue between courts begin with or draw on her work. ${ }^{61}$ Slaughter describes the interactions between courts as "trans-judicial communication," and identifies three types of such interaction. First, she describes "horizontal" dialogue, which includes communication between domestic courts at the same level in different states, ${ }^{62}$ or

\footnotetext{
${ }^{52}$ Philip C. Jessup, Transnational law 2 (1956).

${ }^{53}$ Devika Hovell, A Dialogue Model: The Role of the Domestic Judge in Security Council Decision-Making, 26 LEIDEN J. INT'L L. 579 (2013).

${ }^{54} I d$. at 591 .

${ }^{55} \mathrm{Id}$. at 582 .

${ }^{56} I d$. at 582 .

${ }^{57}$ Roach, supra note 46 , at 540 .

${ }^{58} \mathrm{Id}$. at 554 .

${ }^{59} \mathrm{Id}$.

${ }^{60} \mathrm{Id}$.

${ }^{61}$ See Anne-Marie Slaughter, A Typology of Transjudicial Communication Symposium: Human Rights International Law, 29 U. Rich. L. REv. 99 (1994); Anne-Marie Slaughter, A Global Community of Courts Focus: Emerging Fora for International Litigation (Part 2), 44 Harv. InT'L L.J. 191 (2003); Young, supra note 3; Melissa A. Waters, Mediating Norms and Identity: The Role of Transnational Judicial Dialogue in Creating and Enforcing International Law, 93 GEO. L.J. 487 (2004); Merris Amos, The Dialogue between the United Kingdom and the European Court of Human Rights, 61 InT'L \& CoMPAR. L. Q. 557 (2012); Christopher McCrudden, A Common Law of Human Rights?: Transnational Judicial Conversations on Constitutional Rights, 20 OXFORD J. LEGAL STUD. 499 (2000); Luca Pasquet, Dialogue or Interaction?: A NonCosmopolitan Reading of Transjudicial Communication, in Judicial Dialogue AND Human Rights 467-503 (Amrei Müller ed., 1 ed. 2017); Roach, supra note 46; Ariel E. Dulitzky, An Inter-American Constitutional Court? The Invention of the Conventionality Control by the Inter-American Court of Human Rights, 50 Tex. INT'L L. J. 45 (2015).

${ }^{62}$ Slaughter, supra note 62, at 103; See also Naomi Hart, Complementary Protection and Domestic Courts: The Extent, Method, Purpose and Effects of Judicial Dialogue, in Judicial Dialogue and Human Rights (Amrei Müller ed., 1st ed. 2017); Waters, supra note 62.
} 
communication between different international courts. ${ }^{63}$ Second, she describes as "vertical" dialogue, those interactions between domestic and supranational courts, ${ }^{64}$ whereby: "national courts are able to protect rights in a manner that takes account of specific legal cultures, whilst international and supranational courts are able to ensure that these national protections of human rights do not transgress an accepted minimal protection of human rights." ${ }^{65}$ Third, Slaughter describes "mixed vertical-horizonal" dialogue, where, for example, "supranational tribunals" serve as conduits "for horizontal communication," or where "common legal principles in national legal orders" are "distilled and disseminated by a supranational tribunal." 66

Although not explicitly acknowledged as normative advantages, accounts of dialogue at the international and transnational level, specifically those with respect to interactions between and among courts, do appear to carry distinct normative claims. The most significant normative claim of dialogue in this respect is that it creates a so-called "international rule of law." Slaughter argues that an "international rule of law" is created because judiciaries are bound by a "common commitment to the rule of law," and when courts directly interact with one another there is a "meshing of that commitment." ${ }^{\text {" }}$ A global system of checks and balances is also effectively created as courts can, through interaction, keep the other accountable and uphold the global rule of law. ${ }^{68}$ Merris Amos similarly argues that interaction between and among courts builds the authority of the judiciary globally. ${ }^{69}$ The argument is that this bolsters human rights protections and effects a "rights-enhancing global practice," 70 because the upholding and enforcement of human rights becomes a truly global and common enterprise. ${ }^{71}$ This, accordingly, Amos argues, increases the legitimacy of both domestic and international human rights law. ${ }^{72}$

Dialogue at the international level claims to have other normative advantages, including that of effecting greater deliberation and, in turn, increasing legitimacy for rights adjudication at international law. Aida Torres Perez, for instance, argues that dialogue "acknowledges the plurality of voices, enhances participation in the interpretive process" and by accommodating diverse claims, it "provides a fuller form of legitimacy" for the adjudication of supranational rights. ${ }^{73}$ Eyal Benvenisti and George Downs similarly note that interaction between and among courts generates information, thus, involving in the process a wide and diverse range of political actors and citizens

\footnotetext{
${ }^{63}$ Slaughter, supra note 62 , at 103 . Judges have acknowledged participating in this kind of dialogue: see, e.g., DIALOGUE Across the Atlantic: Selected Case-Law of the European and Inter-American Human Rights Courts (2015) https://www.echr.coe.int/Documents/Dialogue_Across_Atlantic_ENG.pdf.

${ }^{64}$ Slaughter, supra note 62, at 106. See, e.g., Young, supra note 3; Anthony Arnull, Judicial Dialogue in the European Union, in Philosophical Foundations of European Union Law 109 (Julie Dickson \& Pavlos Eleftheriadis eds., 2012); Carlos Ayala, The Judicial Dialogue Between International and National Courts in the Inter-American Human Rights System, in Judges as Guardians of Constitutionalism and Human Rights 306 (Martin Scheinin et al. eds., 2016); Dulitzky, supra note 62; Antonios Tzanakopoulos, Judicial Dialogue as a Means of Interpretation, in THE INTERPRETATION OF INTERNATIONAL LaW by Domestic Courts: Uniformity, Diversity, Convergence 72 (Helmut Philipp Aust \& Georg Nolte eds., 2016); Aida Torres Pérez, Judicial Dialogue and Fundamental Rights in the European Union: A Quest for Legitimacy, in COMPAR. CONST. TheOry 102 (Gary Jacobsohn \& Miguel Schor eds., 2018).

${ }^{65}$ Young, supra note 3, at 10 . Judges have acknowledged taking part in these kinds of interactions: see, e.g., Lord Kerr, Lecture at University College Dublin: The Conversation between Strasbourg and National Courts: Dialogue or Dictation? (Nov. 20, 2009).

${ }^{66}$ Slaughter, supra note 62, at 111-12.

${ }^{67} I d$. at 138.; See also Laurence R. Helfer \& Anne-Marie Slaughter, Toward a Theory of Effective Supranational Adjudication, 107 YALE L.J. 282, 371 (1997).

${ }^{68}$ AnNe-Marie Slaughter, A NeW wOrld order 68-69 (2004). See also Eyal Benvenisti \& George W. Downs, National Courts, Domestic Democracy, and the Evolution of International Law, 20 EurOPEAN J. INT'L L. 59, 69 (2009).

${ }^{69}$ Amos, supra note 62, at 572.

${ }^{70}$ Hart, supra note 62, at 214-15.

${ }^{71}$ Slaughter, supra note 62, at 118, 121-23, 132. See also Anne-Marie Slaughter, Judicial Globalization, 40 VA. J. INT'L L. 1103, 1123 (2000).

${ }^{72}$ Amos, supra note 62, at 572.

${ }^{73}$ Pérez, supra note 65 , at 113.
} 
within the wider community, which "promotes accountability and more effective deliberation' and strengthens democracy." 74 The effect of greater deliberation at this level also, according to Pérez, "contributes to building a common identity" for the global community. ${ }^{75}$ The normative arguments, accordingly, claim that dialogue at international law essentially offers "more human rights, more democracy, more legitimacy, and more legal unity."

\section{Dialogue at Public Law vis-à-vis the International and Transnational Sphere}

It is evident that there are, as would be expected by the use of the same metaphor, similarities between the public law dialogue model and theories of dialogue at international law and the "transnational law" sphere. At a basic level, both accounts of dialogue are about the interactions between and among various institutions. It is clear, however, that there are significant differences in how dialogue is defined and as to what actually constitutes dialogue at public law and international law or "transnational law." These differences are now set out more explicitly to demonstrate that the application of public law dialogue as proposed in this paper represents something new.

There are two clear differences as to what constitutes dialogue at public law and what has been called dialogue in the international sphere. First, the institutions, the interactions of which are being examined in each sphere, are different. There is no directly equivalent "legislature" or elected branch in those accounts of dialogue at the international level. This difference has particular implications for the claimed normative advantages of dialogue in each sphere, as will be discussed below. The second difference is that the nature of the interactions labelled dialogue in each sphere is different.

As discussed, "dialogue" at public law describes, at least in the sense of constitutional collaboration, those interactions with a demonstrated awareness on the part of each institution to the interaction, not only to the reasons given on the particular issue at hand by the other, but as to why those reasons are given and the institutional competence of the other institution to the interaction. That is, "dialogue" at public law involves, in a sense, "active listening" on the part of constitutional institutions. The label of "dialogue" hitherto applied at the international law level, however, is given to interactions of a fairly different nature to that just described at public law.

"Dialogue," as the term has thus far been used at international law, and the "transnational law" sphere, describes interactions that do not necessarily involve an awareness on the part of each institution as to the institutional competence of the other. Rather, the term describes those interactions that involve one institution simply quoting or citing the reasoning of the other institution. As Geoffrey Sigalet, Gregoire Webber, and Rosalind Dixon describe it, with respect to court-tocourt dialogue, 'dialogue' includes the mere borrowing, of "doctrines, principles, modes of reasoning, and argument from the opinions of foreign and international courts and the texts of foreign constitutions and international treaties."77

The starkest example of this is how Slaughter employs the term dialogue, specifically, "horizontal dialogue," to describe interactions whereby one domestic court simply cites the judgment or reasoning of another domestic court without evidencing an understanding of the particular institutional position or competence of that other court or, significantly, without the knowledge of that other court. Unlike public law dialogue, which is guided by constitutional mechanisms, these interactions at international law and the "transnational law" sphere which have been called "dialogue" are more decentralized. It is for this reason that accounts of dialogue at the

\footnotetext{
${ }^{74}$ Eyal Benvenisti \& George W. Downs, Between Fragmentation and Democracy: The Role of National and INTERNATIONAL COURTS 12, 168 (2017).

${ }^{75}$ Pérez, supra note 65 , at 107.

${ }^{76}$ Pasquet, supra note 62 , at 480.

${ }^{77}$ Geoffrey Sigalet et al., Introduction: The 'What' and 'Why' of Constitutional Dialogue, in CONSTITUTIONAL Dialogue 18 (Geoffrey Sigalet et al. eds., 1st ed. 2019).
} 
international level, at least in the sense of court-to-court dialogue, often draw criticism for giving judges undue discretion and for allowing judges to "cherry pick" to suit their arguments. ${ }^{78}$ These are hardly dynamic interactions, in the same sense as interactions referred to as "dialogue" at public law. Slaughter acknowledges that such interactions are more aptly described as monologues. $^{79}$

The differences in the institutions to the interactions, and in the nature of the interactions, labelled "dialogue" at public law and at the international level, influence the normative advantages that dialogue is said to achieve in each sphere. On the one hand, the key normative claim at public law is, as set out, that dialogue offers a "better protection of rights." This is precisely because it provides for a protection of rights that draws on the strengths of how courts reason about rights, but also, significantly, on how legislatures reason about rights. Public law dialogue can be criticized on this basis for undermining the rule of law by its forsaking a strong protection of rights for a weakened protection that takes account of political opinion. On the other hand, the central normative claim of dialogic accounts in the international sphere, at least with respect to courtto-court dialogue, is that dialogue establishes a "global rule of law" by strengthening the legal protection of rights and ignoring, or at least limiting, the political. This is why accounts of dialogue that thus far exist at the international level can draw criticism for undermining or wearing away domestic rights in constitutions or bill of rights, ${ }^{80}$ for circumventing domestic checks and balances and, on one view, democratic accountability more generally, ${ }^{81}$ and, in turn, for causing domestic courts to "lose legitimacy in the eyes of domestic audiences." 82 This is not a criticism that could be levelled at public law dialogue.

The application of the public law dialogue model proposed in this paper is, accordingly, different from accounts of dialogue that exist so far at international law and the "transnational law" sphere. It involves examining different kinds of interactions with the aim of achieving a different set of normative advantages.

\section{Applying Public Law Dialogue to the Relationship Between the European Courts and Domestic Legislatures}

The article now examines whether the public law dialogue model can provide an explanatory framework for interactions between domestic political branches and the European Courts. The section is structured in two sections. ${ }^{83}$ The first explores, necessarily at a high level of generality, the institutional and constitutional differences between domestic legislatures and the European Courts. The second examines exactly how interactions are facilitated between state legislatures and the European Courts. By drawing close analogies with those mechanisms identified by Hogg and Bushell in the Canadian Charter, it identifies the relevant mechanisms in each case study that facilitate dialogue between state legislatures and the ECtHR and the CJEU, respectively.

\footnotetext{
${ }^{78}$ Judicial Dialogue and Human Rights, 10 (Amrei Müller \& Hege Elisabeth Kjos eds., 2017); Ronald J. Jr. Krotoszynski, I'd Like to Teach the World to Sing (In Perfect Harmony): International Judicial Dialogue and the Muses - Reflections of the Perils and the Promise of International Judicial Dialogue 2006 Survey of Books Relating to the Law - Part V: International and Comparative Law, 104 Mich. L. REv. 1321, 1333 (2005); McCrudden, supra note 62, at 517, 530.

${ }^{79}$ Slaughter, supra note 62, at 113.

${ }^{80}$ See Robert J. Delahunty \& John Yoo, Against Foreign Law, 29 Harv. J.L. \& Pub. Pol’y 291 (2006).

${ }^{81}$ Judicial Dialogue and Human Rights, supra note 79, at 10; Miguel Schor, Mapping Comparative Judicial Review, 7 Wash. U. Glob. Stud. L. Rev. 257 (2007); RAN Hirschl, Towards JuRISTOCRACY: The Origins AND CONSEQUENCES OF THE New Constitutionalism (2004); Cf. Benvenisti and Downs argue that interaction between and among courts promote democratic accountability because the interaction can constrain domestic executives' growth in, and abuse of, power, see Eyal Benvenisti \& George W. Downs, Toward Global Checks and Balances, 20 Const. Pol. Econ. 366 (2009).

${ }^{82}$ Waters, supra note 62 , at 559.

${ }^{83}$ This structure generally follows Young's analysis of dialogue between UK courts and the European courts. See YouNG, supra note 3 .
} 


\section{Differences Between the European Courts and Domestic Legislatures}

The institutional and constitutional differences between the European Courts and domestic legislatures are explored in order to work out the extent to which dialogue may be facilitated, given that, as Young notes, the differences between two institutions are what influence interactions and thus facilitate dialogue in the sense of supporting a combination of different ways of reasoning about rights. ${ }^{84}$

These differences are of course not the only conditions that might facilitate whether and how dialogue takes place. Social, political, and historical differences are, to take one example, also likely to influence the nature of the relationship between state legislatures and the European Courts. The fact that most European states are democratic, for instance, inevitably impacts the nature of the interactions between the two and, in particular, how the European Courts are received and perceived by European states. Haddad and others have discussed, for example, with respect to the ECtHR, that the fact that most European states are democratic has meant that the court has, by and large, looked primarily at cases concerning restrictions on the right to a fair trial or on the right to freedom of expression. They note that this is different from the Inter-American Court of Human Rights, the cases before which have more often involved human rights issues involving, for instance, grievous bodily harm. ${ }^{85}$

Although a full exploration of these other conditions and differences is beyond the scope of this article; social, political, and historical differences themselves of course influence those institutional and constitutional differences between national legislatures and the European Courts which are now discussed in detail.

\section{Institutional Differences}

An examination of the institutional differences between state legislatures and the ECtHR, and between state legislatures and the CJEU requires looking at the purpose, role, and relative expertise of each, and the different perspective each might bring to bear on rights issues. ${ }^{86}$

The ECtHR and the CJEU are courts that exist at international law. Specifically, the ECtHR is a regional human rights court which ensures that states' parties uphold their obligations to ensure and guarantee the rights under the European Convention. ${ }^{87}$ In light of the primacy of EU law, the CJEU can be described as a supra-national court which adjudicates on all matters arising under EU law. ${ }^{88}$ The basic purpose of a domestic legislature is to make and amend laws for a particular jurisdiction. Domestic constitutions usually confer this role on the legislature and provide constraints on the exercise of the role.

Some general conclusions can be drawn about the institutions' relative expertise in the area of human rights, in light of those roles. As Young says, the ECtHR should be expected to have greater expertise in human rights, given that the determination of human rights issues is its sole purpose and focus, at least vis-à-vis the CJEU. ${ }^{89}$ However, while the CJEU may be a general court, and human rights determinations may seem to form only a small part of its workload, it is the body charged with considering issues arising under the Charter of Fundamental Rights of the European

\footnotetext{
${ }^{84} I d$. at 258.

${ }^{85}$ Heidi Haddad, Judicial Institution Builders: NGOs and International Human Rights Courts, in GLOBALIZING HUMAN Rights: Emerging Issues AND Approaches 126, 135 (Charles Smith ed., 2013); Pablo Contreras, National Discretion and International Deference in the Restriction of Human Rights: A Comparison Between the Jurisprudence of the European and the Inter-American Court of Human Rights, 11 Nw. U. J. INT'L HuM. RTs. 28, 29, 56-57 (2012).

${ }^{86}$ See Young, supra note 3, at 257-60.

${ }^{87} \mathrm{See}$ ECHR for the Protection of Human Rights and Fundamental Freedoms, as amended by Protocols Nos. 11 and 14, 4 November 1950, art. 19 ("ECHR"). Note that Slaughter and Helfer refer to the ECtHR as a "supra-national court," see Helfer \& Slaughter, supra note 68.

${ }^{88}$ Treaty of the European Union, Oct. 26, 2012, 2012 O.J. (C 326/13), art. 19(1).

${ }^{89}$ Young, supra note 3, at 257.
} 
Union..$^{90}$ Moreover, it protects the fundamental rights found in the general principles of EU law, and the CJEU has held that, "the applicability of European Union law entails the applicability of the fundamental rights guaranteed by the Charter." domestic legislatures in human rights issues might be somewhat less than, say, the ECtHR, because the consideration of such issues only forms a small part of the legislative role. Domestic legislatures can, however, draw on decades, if not centuries, of institutional experience with respect to human rights issues. In light of a legislature's direct accountability to its domestic constituency, and often the constitutionally entrenched position of domestic bills or charters of rights, such legislatures must usually consider the human rights implications of all laws.

In terms of the perspective each institution brings to rights issues, the ECtHR and the CJEU inevitably have a more comprehensive understanding of the rights issues in the European region than, say, a domestic legislature in Europe would have. Cases come before the ECtHR primarily by individual application. ${ }^{92}$ As Young notes, this means that the ECtHR must undertake an assessment of the conclusion first reached by the domestic court that there was no Convention breach and this then builds the ECtHR's perspective on how Convention rights are understood and implemented across the European region. ${ }^{93}$ Further, the ECtHR hears submissions from states' parties to proceedings and, in addition, can hear submissions from other signatory states not party to the specific case before the court as to their view of the rights issue at hand. ${ }^{94}$ Cases come before the CJEU either by "direct actions," or usually, by domestic courts referring questions of EU law under Article 267 of the Treaty on the Functioning of the European Union. ${ }^{95}$ Domestic courts provide information to the CJEU to give the latter "a clear understanding of the actual and legal context of the main proceedings." 96 Domestic courts may also give their own view as to what the answer to the question is and should be. ${ }^{97}$ Pérez notes that, in practice, this reference procedure is "used to question the compatibility of domestic legislation with EU law, including EU fundamental rights." ${ }^{98}$ Member states can also intervene in proceedings before the CJEU and give their opinion on the rights issue at hand. In a similar manner to the ECtHR, the CJEU can thus build a broad regional perspective on rights issues.

Although domestic laws may have extra-territorial effect, domestic legislatures essentially make laws for the particular jurisdiction in which they are situated and parliamentarians remain accountable to the domestic constituency. Domestic legislatures seldom have to take comparative or international perspectives into account. State legislatures accordingly would, at least in theory, have a better and deeper perspective on human rights matters within their own country, at least with respect to their own citizens, than, say, an international court might have.

\section{Constitutional Differences}

An examination of the differences in constitutional positions between domestic legislatures and the ECtHR and CJEU respectively, involves examining how domestic legislatures must treat the decisions of those international courts and the relationship between domestic and international law.

\footnotetext{
${ }^{90}$ Charter of Fundamental Rights of the European Union, March 30, 2010, 2010 O.J. (C 83/389) [hereinafter EU Charter].

${ }^{91}$ Case C-617/10, Áklagaren v. Fransson, 2013 E.C.R. 21.

${ }^{92} \mathrm{ECHR}$, art. 34. State parties may also refer cases to the CJEU. See ECHR art. 33.

${ }^{93}$ YOUNG, supra note 3, at 256.

${ }^{94} \mathrm{Id}$. at $257-58$.

${ }^{95}$ Treaty on the Functioning of the European Union, July 6, 2016, 2016 O.J. (C 202/1) 1 [hereinafter TFEU]. See EUROPEAN UNION LAW 262-309 (Catherine Barnard \& Steve Peers eds., 2d ed., 2017).

${ }^{96}$ Recommendations to National Courts and Tribunals in Relation to the Initiation of Preliminary Ruling Proceedings, 2012 O.J. (C 338/1) 22.

${ }^{97}$ Information Note on References from National Courts for a Preliminary Ruling, 2005 O.J. (C 143/1) 24.

${ }^{98}$ Pérez, supra note 65 , at 117.
} 
The ECtHR is an international court, and, specifically, a regional human rights court. It is not a superior court to national courts of the signatory states of the ECHR. It does not hear appeals from national courts, with its judgment replacing the domestic court judgment. ${ }^{99}$ Article 46(1) of the ECHR provides that member states must abide by the final judgment of the ECtHR in cases to which they are parties. As Young points out, however, states are able to determine the nature of their relationship with the ECtHR. ${ }^{100}$ Moreover, in spite of what Article 46 provides, state legislatures and courts can choose to ignore or disregard judgments of the ECtHR and its reasoning, and, as a more general matter, domestic law determines the extent to which international law applies.

In contrast, EU member states, generally speaking, must implement the CJEU's decisions. The CJEU determines EU law, and it is a condition of EU membership that member states accept that, in circumstances where there is a conflict between domestic law and EU law, the latter prevails. ${ }^{101}$ However, EU law only applies because member states allow it to and states can ultimately decide how domestic law and EU law relate. ${ }^{102}$ Furthermore, a member state can always refuse to amend relevant domestic legislation to reflect a CJEU decision, or a member state can simply ignore a CJEU decision, leaving it to domestic courts to decide how the law should be applied where a specific conflict arises. ${ }^{103}$

\section{The Relationship Between European Courts and Domestic Legislatures \\ 1. The ECtHR and Domestic Legislatures}

It is possible to identify several mechanisms in the ECHR, as well as mechanisms that have been developed by the ECtHR, that facilitate the interactions between the ECtHR and state legislatures in a manner that reflects those differences set out above. Many of these mechanisms are similar both to those Hogg and Bushell identified in the Canadian Charter as facilitating dialogue between the Canadian judiciary and legislature and to those Gardbaum identified in other commonwealth constitutional models as giving rise to relationships of dialogue between constitutional institutions. Accordingly, for ease of understanding, analogies are made between the mechanisms identified in the Canadian Charter and those in the ECHR before turning to show how these mechanisms function in practice to facilitate dialogue between domestic legislatures and the ECtHR.

As set out earlier, section 1 of the Canadian Charter provides that rights guaranteed in the Charter can be subjected to reasonable limits. According to Hogg and Bushell, where a court rules that a law violated the Charter on the basis that a right was not reasonably limited, the court will usually explain why that standard was not met and explain what a less restrictive law would look like. This allows the legislature to respond in an appropriate way; that is, in such a way that would not violate the Charter and that would still achieve the legislature's own goals. ${ }^{104}$ It is thus a mechanism that, to use Young's term, gives rise to constitutional collaboration because it allows the court and the legislature to work together on the rights issues and do so in a way that maximizes the strengths of each institution.

\footnotetext{
${ }^{99}$ YounG, supra note 3, at 260.

${ }^{100} \mathrm{Id}$. at 259.

${ }^{101}$ Id. at 276-77. See, e.g., Case C-26/62, Van Gend v Netherlands Inland Revenue Admin., 1963 E.C.R. 1; See, e.g., Case C106/77, Amminstrazione delle Finanze dello Stato v Simmenthal SpA, 1978 E.C.R. 629.

${ }^{102}$ YounG, supra note 3, at 277. Young points to the following to demonstrate this in the UK context: Thoburn v Sunderland City Council [2003] QB 151 (Eng.).; R (HS2) v Sec'y of State for Transp. [2014] UKSC 3; European Union Act 2011, c. 12, \$18 (Eng.).

${ }^{103}$ See discussion in Pérez, supra note 65, at 114.

${ }^{104}$ Hogg \& Bushell, supra note 7 , at 85 .
} 
A similar mechanism can, arguably, be found at various points in the ECHR. Article 8 of the ECHR, for example, sets out the Right to Respect for Private and Family Life, and Article 8(2) provides that:

[T] here shall be no interference by a public authority with the exercise of this right except such as in accordance with the law and is necessary in a democratic society in the interests of national security, public safety or the economic well-being of the country, for the prevention of disorder or crime, for the protection of health or morals, or for the protection of the rights and freedoms of others. ${ }^{105}$

The Freedom to Manifest One's Religion or Beliefs in Article 9 of the ECHR, the Right to Freedom of Expression in Article 10 and the Right to Freedom of Assembly and Association in Article 11, for instance, can similarly be limited where the limitations are: (i) Prescribed or are in accordance with law; (ii) where the limitations are "necessary in a democratic society"; and (iii) are in the interests of, for example, national security, territorial integrity, public safety, for the prevention of disorder or crime, for the protection of public order, health or morals, or for the protection of the rights and freedoms of others. ${ }^{106}$

Hogg and Bushell also identified "qualified rights" as mechanisms for facilitating dialogue in the Canadian context. Qualified rights "admit of the possibility of corrective legislative action after a judicial decision has struck down a law for breach of one of the rights." ${ }^{07}$ The legislature can pass a new law that satisfies the judiciary's standard of reasonableness or arbitrariness, while still achieving its own goals. Dialogue is thereby facilitated, again in the sense of constitutional collaboration, by these kinds of mechanisms. Qualified rights, in the sense described by Hogg and Bushell, can also be found in the ECHR. The right to liberty and security in Article 5 of the ECHR, and the right to a fair trial in Article 6, for example, can be limited in various ways, as long as that limitation is "reasonable."

The guarantee of equality rights, and their satisfaction through remedial measures, was also identified as being a dialogic mechanism by Hogg and Bushell. Hogg and Bushell point out that, where a law violates section 15 of the Canadian Charter, which prohibits discrimination, the judicial decision usually results in the legislature needing to accommodate the excluded individual or group. Yet, this can be achieved in different ways, allowing "the competent legislative bodies to set their own priorities," while respecting the judicial decision. ${ }^{108}$ It thus facilitates dialogue in the sense of constitutional collaboration. A similar mechanism to section 15 of the Canadian Charter can be found in Article 14 of the ECHR, which prohibits discrimination on various grounds. Violations of Article 14 are found in conjunction with violations of other rights in the ECHR.

In addition to these mechanisms in the ECHR, the margin of appreciation doctrine, which has been developed by the ECtHR, also arguably facilitates dialogue between domestic legislatures and the ECtHR itself, and assists those mechanisms in the ECHR, set out above, to facilitate dialogue. The doctrine is based on the idea, broadly speaking, that a state should be given some "latitude in resolving the inherent conflicts between individual rights and national interests or among different moral convictions." 109 The ECtHR first invoked the doctrine in Handyside v. United Kingdom, and justified it as follows:

\footnotetext{
${ }^{105}$ Emphasis added.

${ }^{106}$ The right to freedom of expression can also be limited to protect the reputation or rights of others, to prevent the disclosure of information received in confidence, or to maintain the authority and impartiality of the judiciary.

${ }^{107}$ Hogg \& Bushell, supra note 7 , at $87-88$.

${ }^{108}$ Id. at $90-91$.

${ }^{109}$ Eyal Benvenisti, Margin of Appreciation, Consensus, and Universal Standards Symposium Issue: The Proliferation of International Tribunals: Piecing Together the Puzzle, 31 N.Y.U. J. INT'L L. \& POL. 843, 843-44 (1998).
} 
By reason of their direct and continuous contact with the vital forces of their countries, State authorities are in principle in a better position than the international judge to give an opinion on the exact content of these requirements as well as on the 'necessity' of a 'restriction' or 'penalty' intended to meet them .... ${ }^{110}$

The ECtHR has held, however, that the margin granted "goes hand in hand with a European supervision," 111 and accordingly, as Contreras says, it is a legal vehicle that attempts to "balance the universal aspect of human rights with the local and domestic peculiarities of each state." 112 The doctrine facilitates dialogue in the sense of constitutional collaboration because it allows the ECtHR to make sure that the state does not fall below the minimum protection offered by the Convention right, and, at the same time, it gives the state discretion and "a margin" in its response. This allows the state to respond to the international court with new legislation that can achieve its own goals. The ECtHR thus, as Young says, recognizes, in using the margin of appreciation doctrine, "that the rights issue may be better resolved at the domestic as opposed to the European level."113

An example of how these mechanisms in the ECHR facilitate dialogue between state legislatures and the ECtHR, and do so in the sense of constitutional collaboration, can be seen in Biao $v$ Denmark. ${ }^{114}$ This case, and the example employed later with respect to the relationship between national legislatures and the CJEU, has been chosen given the contestable nature of the right of non-nationals to enter and remain in a country. The applicant in Biao was a Danish national whose wife was refused residency in Denmark. To be afforded a residency permit, the applicant and his wife needed to show that their ties to Denmark, when considered together, were as strong or stronger than their attachment to any other country, or that the applicant had been a Danish national for more than twenty-eight years. The residency permit was refused on the basis that their combined attachment to Ghana was viewed as stronger than their attachment to Denmark, and as the applicant had only been a Danish national for two years, he did not fall within the twentyeight-year exception. ${ }^{115}$ The Grand Chamber of the ECtHR held that the relevant law discriminated against naturalized Danish nationals whose ethnic origin was not Danish, and thus was in breach of Article 14, in conjunction with Article 8 of the ECHR. ${ }^{116}$

In coming to its finding, the Grand Chamber acknowledged that the state's motivation was to:

[C]ontrol immigration and improve integration with regard to 'both resident foreigners and resident Danish nationals of foreign extraction' whose 'widespread marriage pattern' was to 'marry a person from their country of origin,' and ... to ensure that the attachment requirement did not have unintended consequences for 'persons such as Danish nationals who opted to live abroad for a lengthy period and who started a family while away from Denmark.' ${ }^{\text {'17 }}$

The Grand Chamber recognized that states are better placed to determine rights issues in the areas of social and economic strategy, providing that "states enjoy a certain margin of appreciation in assessing whether and to what extent differences in otherwise similar situations justify a difference

\footnotetext{
${ }^{110}$ Handyside v. United Kingdom, App. No. 5493/72, para. 48 (Dec. 7, 1976) https://www.bailii.org/eu/cases/ECHR/1976/5. html\#para48 [hereinafter Handyside]. The doctrine has since been given more formal application in Protocol no 15 (2013) to the ECHR.

${ }^{111} I d$. para. 49.

${ }^{112}$ Contreras, supra note 86 , at 32 .

${ }^{113}$ Young, supra note 3, at 258.

${ }^{114}$ Biao v. Denmark, App. No. 38590/10, (May 24, 2016), https://hudoc.echr.coe.int/fre\#\{\%22itemid\%22:[\%22001-163115\% 22]\} [hereinafter Biao].

${ }^{115} I d$. paras. $10-31$.

${ }^{116} \mathrm{Id}$. para. 139.

${ }^{117} I d$. para. 124.
} 
in treatment," and that the margin is particularly wide in those areas. ${ }^{118}$ However, it added that "very weighty reasons would have to be put forward before the Court could regard a difference in treatment based exclusively on the ground of nationality as compatible with the Convention."119 The Grand Chamber seemed to suggest that an exemption to the attachment requirement would remain in breach of the convention so long as it "depends solely on the length of nationality, whether for twenty-eight years or less."

In response to Biao and, it seems, to that particular suggestion on the part of the Grand Chamber, the Danish legislature abolished the exemption to the attachment requirement (ie the "28-year rule") ${ }^{121}$ by amending section 9(7) of the Aliens Act. ${ }^{122}$ In doing so, the state legislature in effect recognized the competence of the Grand Chamber to set the minimum standard of international law, namely, that the law must not be discriminatory. Importantly, however, it did so in such a way as to achieve its original policy objective, that being to control and restrict immigration. This is because the effect of removing the exemption was that the attachment requirement applied to everyone, meaning that immigration to Denmark was made more difficult because all married couples would need to show that their ties were stronger to Denmark than another country, including those who had been Danish nationals for more than twenty-eight years. ${ }^{123}$ Accordingly, rights were protected in a way that drew on the strengths of how the ECtHR and state legislatures reason about rights; the ECtHR's reasoning was focused on the individual and ensured that the rights protection did not go below a minimum standard, and the Danish legislature, while respecting that minimum standard, was able to still achieve its key policy objectives and thus produce a democratically sound protection of rights.

There are also mechanisms that facilitate dialogue between national legislatures and the ECtHR in the sense of constitutional counter-balancing, in a similar manner to section 33 of the Canadian Charter, which confers on the Canadian legislature the power to override a judicial decision. As noted above, state legislatures can, for instance, simply ignore a decision of the ECtHR, openly refuse to follow the decision based on the belief that the decision is incorrect, or recognize the decision and then not follow it for other reasons.

\section{The CJEU and Domestic Legislatures}

Despite the primacy of EU law, the EU system should not be seen as a single "integrated" legal system where the international court is hierarchically superior to member state decisions. It is, rather, pluralistic and interactive, ${ }^{124}$ and mechanisms in the EU system facilitate interactions between the CJEU and domestic legislatures.

There are, for example, mechanisms in the EU Charter, which codified the CJEU's traditional approach to rights issues ${ }^{125}$ which may facilitate dialogue between national legislatures and the CJEU. As discussed, the CJEU has held that the EU Charter applies to states when applying EU law. Analogies can again be drawn between those mechanisms identified by Hogg and Bushell in the Canadian Charter and those in the EU Charter.

Article 52(1) of the EU Charter, for instance, provides as follows:

\footnotetext{
${ }^{118} I d$. para. 93.

${ }^{119} I d$.

${ }^{120} I d$. para. 125 .

${ }^{121}$ The 28-year rule had been amended to a 26-year rule prior to the Grand Chamber's judgment.

${ }^{122}$ Act no. 504 of 23 May 2017, Danish Law Gazette on 24 May 2017. See Ministry of Immigration and Integration, 'International Migration - Denmark' (OECD Report 2017) 40.

${ }^{123}$ See Danes with Foreign Spouses to be Hit by New Restriction, THE Local (June 29, 2016), https://www.thelocal.dk/ 20160629/denmark-makes-it-harder-for-foreign-spouses-to-come.

${ }^{124}$ YounG, supra note 3, at 277.

${ }^{125}$ See Explanations Relating to the Charter of Fundamental Rights, 2007 O.J. (C 303/02) 17; MARGOT HorspoOL, EUROPEAN UNION LAW $\$ \$ 6.60-6.125$ (9th ed. 2016).
} 
Any limitation on the exercise of the rights and freedoms recognised by this Charter must be provided for by law and respect the essence of those rights and freedoms. Subject to the principle of proportionality, limitations may be made only if they are necessary and genuinely meet objectives of general interest recognised by the Union or the need to protect the rights and freedoms of others. ${ }^{126}$

Where, for example, the CJEU rules on a point of EU law that engages rights, this provision can operate to give the state some scope to pursue its own agenda in response, while still implementing EU law and the CJEU's interpretation of that law. In this sense, the article seems analogous to the general limitation provision in section 1 of the Canadian Charter that, for reasons set out earlier, Hogg and Bushell identified as a key dialogic mechanism. Significantly, the CJEU has used Article $51(2)$ as a more general interpretive tool. ${ }^{127}$

Article 21 of the EU Charter also prohibits discrimination on the grounds set out in the article. Accordingly, for those same reasons set out in relation to Article 15 of the Canadian Charter and Article 14 of the ECHR, Article 21 of the EU Charter can facilitate dialogue between domestic legislatures and the CJEU in the sense of constitutional collaboration.

The CJEU can also, as Young explains, "exercise comity" by formulating decisions in such a way that it provides an opinion on the rights issue at hand, while also leaving space for resolution of the issue at the national level. ${ }^{128}$ Young notes that one such way the CJEU exercises comity is when it modifies the applicable proportionality standard. ${ }^{129}$ Although Young makes this argument with respect to interactions between national courts and the CJEU, it can also, arguably, function to facilitate dialogue in the sense of constitutional collaboration between state legislatures and the CJEU. While the case of Gerardo Ruiz Zambrano $v$ Office national de l'emploi was subsequently limited somewhat in McCarthy v. Secretary of State for the Home Department ${ }^{130}$ and Dereci and Others $v$. Bundesministerium, ${ }^{131}$ it provides a particularly interesting example of how dialogue can occur in this way. Significantly, the case did not involve a cross-border element, until that point considered to be necessary to trigger EU law, and it demonstrates the outer limits of how much each institution is willing to accommodate and acknowledge the competence of the other.

Zambrano concerned the refusal to the applicant (Zambrano) of a residency permit to remain in Belgium. Zambrano was a Colombian national, but his two children were Belgian citizens by virtue of their birth in Belgium and their parents not registering them for Colombian nationality. ${ }^{132}$ The CJEU held that:

Article 20 TFEU is to be interpreted as meaning that it precludes a Member State from refusing a third country national upon whom his minor children, who are European Union citizens, are dependent, a right of residence in the Member State of residence and nationality of those children, and from refusing to grant a work permit to that third country national, in so far as such decisions deprive those children of the genuine enjoyment of the substance of the rights attaching to the status of European Union citizen. ${ }^{133}$

The Zambrano judgment is short, but it is possible to gleam from it, drawing on the more detailed reasoning of the Advocate General, an understanding that there are aspects of the rights

\footnotetext{
${ }^{126}$ Emphasis added.

${ }^{127}$ Giorgio Monti, European Union Law: Cases and Materials 248 (2d ed. 2010).

${ }^{128}$ Young, supra note 3, at 282.

${ }^{129} \mathrm{Id}$. at 282.

${ }^{130}$ Case C-434/09, McCarthy v. Secretary of State for the Home Department, 2011 E.C.R. I-03375 [hereinafter McCarthy].

${ }^{131}$ Case C-256/11, Dereci and Others v. Bundesministerium für Inneres, 2011 E.C.R. I-11315 [hereinafter Dereci].

${ }^{132}$ Case C-34/09, Gerardo Ruiz Zambrano v Office national de l'emploi, 2011 E.C.R. 1-01177 paras. 14-35 [hereinafter Zambrano].

${ }^{133} I d$. para. 42.
} 
issue that are better suited for determination by the state legislature. For example, the CJEU recognized explicitly that it is for member states to determine the conditions for the acquisition of nationality, here being Belgian nationality. ${ }^{134}$ But it noted that "citizenship of the Union is intended to be the fundamental status of nationals of the Member States" and so national measures must not deprive such nationals from enjoying the substance of the rights they have by virtue of their being Union citizens. ${ }^{135}$ In the Advocate General's analysis, under the heading of "proportionality," it is evident, however, that this standard can be modified. The Advocate General, in directly addressing what she terms the "floodgates" arguments made by the intervening governments, noted that while the base-line position is that states must exercise their competence to confer domestic nationality in accordance with EU law, ${ }^{136}$ if "particular rules on the acquisition of nationality are-or appear to be - liable to lead to 'unmanageable' results, it is open to the Member State concerned to amend them as to address the problem." ${ }^{137}$ While the Advocate General's Opinion is, of course, not formally part of the judgment, it sheds light on the CJEU's decision.

The CJEU also, although implicitly, arguably demonstrated its view, by the very specificity of its finding, that the state is in a better position to determine some aspects of the rights issue. The CJEU's finding, with respect to Article 20 of the TFEU, did not provide more than was necessary, only examining how the right was to be interpreted with respect to situations where a third country national had minor dependent children who enjoy EU citizenship. Of course, the specificity of the response is also to some degree a consequence of the fact that cases come before the CJEU by way of domestic courts referring specific questions to it under Article 267 of the TFEU. In light of the questions asked by the Belgian court here, however, the CJEU's response appears to be deliberately precise, quite plausibly so as not to reach into the state's competences.

In response to Zambrano, the Belgian legislature amended the 1980s Belgian Nationality Act to introduce new restrictions on family reunification in Belgium. ${ }^{138}$ The legislature provided that non-Belgian parents could join and remain with their child in Belgium, provided that the child was a minor and a Belgian national. The legislature thus complied with the CJEU's judgment. At the same time, however, the legislature also restricted the rights Belgian nationals had previously enjoyed with respect to family reunification, meaning, for instance, that Belgian nationals could no longer bring adult children to Belgium, and that Belgian nationals wishing to bring non-national spouses or partners to Belgian needed to satisfy various socio-economic conditions, such as having adequate housing, a regular and stable income, health insurance and sufficient resources. ${ }^{139}$ The Belgian legislature was thus able to acknowledge the CJEU's institutional strength in setting the minimum standard of the protection of rights, but also asserted its competence and achieve its own political protection of

\footnotetext{
${ }^{134} I d$. para. 40.

${ }^{135} I d$. para. 41.

${ }^{136} I d$. paras. $105,109,115,162$.

${ }^{137} I d$. para. 115.

${ }^{138}$ Law of July, 8 2011, amending the Immigration Act regarding the conditions for family reunification, Belgian Official Gazette of September 22, 2011. See also Moritz Baumgärtel \& Barbara Oomen, Pulling Human Rights Back In? Local Authorities, International Law and the Reception of Undocumented Migrants, $51 \mathrm{~J}$. of Legal Pluralism \& UnOfFicial L. 172 (2019).

${ }^{139}$ See Nathan Cambien, The Impact of Union Citizenship on Member State Immigration Laws: Some Potentially Perverse Side-Effects Resulting from Recent ECJ Case Law 22 (Dec. 16, 2012), https://papers.ssrn.com/sol3/papers.cfm?abstract_id= 2189492; European Migration Network, Family Reunification with Third Country National Sponsors in Belgium: Study of the Belgian Contact Point of the European Migration Network 14 (2017); Yves Pascouau, European Policy Centre, Conditions for Family Reunification under Strain: A comparative Study IN Nine EU Member States 2011; Francesca Strumia, Ruiz Zambrano's Quiet Revolution, in EU LAW STORIES: Contextual and Critical Histories of European Jurisprudence 224 (Nicola Fernanda \& Bill Davies eds., 2017).
} 
rights by amending the Belgian law in such a way that it could still achieve its original policy objective of restricting immigration. ${ }^{140}$

Mechanisms can also be identified that facilitate dialogue between national legislatures and the CJEU in the sense of constitutional counter-balancing. As discussed earlier, a state legislature can always openly refuse to amend relevant domestic legislation to reflect a CJEU decision, can simply ignore a CJEU decision, or leave it to domestic courts to determine how the law should be applied where a specific conflict arises between national law and EU law.

\section{The Utility of Applying Public Law Dialogue to the Relationship Between Domestic Legislatures and the European Courts}

The above analysis has shown that interactions occur between state legislatures and the ECtHR and between state legislatures and the CJEU. These interactions reflect the differences between the institutions and are facilitated by various mechanisms. It is thus possible to describe the relationship between state political branches and the European Courts as one of dialogue, in the public law sense.

Providing an explanatory framework of how state legislatures and the European Courts interact is in itself useful because it allows us both to see that interactions take place and to understand how they take place. This section, however, examines the utility of applying the public law dialogue model in the way set out in Part C, beyond providing a descriptive theory. Specifically, it examines whether the claimed normative advantages of the public law model are also translated across to the interactions between domestic legislatures and the European Courts, and, if so, whether this is in fact desirable, and whether there should be some limitation on the application of the model in this way.

\section{The Normative Claims of Public Law Dialogue at the International Level}

The key normative advantage of public law dialogue is that it provides a "better protection of rights," in that it produces a protection which draws upon accounts of both legal constitutionalism and political constitutionalism. A "better protection of rights" is arguably also achieved when the dialogue model is applied to the interactions between the European courts and domestic legislatures. The mechanisms identified in Part $\mathrm{C}$ appear to generate interactions between state legislatures and European Courts in a way that maximizes the advantages of each institution, and this was seen in the particular examples set out. Although the ECtHR and the CJEU are, like domestic courts, situated in a particular socio-political context, they provide a legal protection of rights in a way that reflects the fact that they are impartial forums of principle and that their focus is on individual or on minority interests, as each ensures that the minimum protection of the right at issue is upheld. In Biao, for example, the ECtHR provided for the minimum standard of the right, namely, that it cannot be discriminatory, while in Zambrano, the CJEU provided in effect that, at a minimum, minors who were EU citizens could not be without their parents. The domestic legislatures, however, could, in these cases, still achieve their objectives as elected bodies and could thus provide a more democratic protection of rights.

The other normative claims of public law dialogue are also arguably achieved by the application of the model in the proposed way. The interactions between state legislatures and the European courts in the sense set out above, for example, appear to lead to greater deliberation with more discussion about rights issues and more voices heard than would be the case if only the legislature or just the international court were determining the rights issue. Benvenisti and Downs have

\footnotetext{
${ }^{140}$ The amendment was effective and family reunification grants dropped. See EUROPEAN Migration NETwORK, MisuSE of the Right to Family Reunification: Marriages of Convenience and False Declarations of Parenthood 4 (2012).
} 
argued that courts "become venues for public participation through NGOs and other representatives of civil society acting as either claimants or amici." ${ }^{141}$ In Biao, for example, the ECtHR set out in its judgment, a comparative law survey, ${ }^{142}$ and, among others, the views of the Council of Europe Commissioner for Human Rights, ${ }^{143}$ the Committee of Ministers, ${ }^{144}$ and the Centre for Advice on Individual Rights in Europe. ${ }^{145}$ In Zambrano, the CJEU heard from, in addition to the applicant and the Belgian Government, seven additional governments and the European Commission. ${ }^{146}$ When the European Courts then interact with state legislatures in the manner set out in Part $\mathrm{C}$, this in effect also brings these voices and views to the attention of the legislature, which might otherwise not have engaged with them. As Rosalind Dixon says, "international or transnational human rights mechanisms may offer a direct counter to legislative blind spots and inertia in some domestic systems." 147

An effective system of checks and balances is also arguably achieved at the international level by the application of the domestic dialogue model. The engaging in dialogue by the European Courts and state legislatures allows those courts to provide a "check" on domestic legislatures to ensure that rights protection does not go below a minimum standard, and domestic legislatures can, in turn, "check" that the court has stayed within its mandate-for instance, by limiting the application of the court's decision at domestic law. An example of how dialogue can achieve an effective system of checks and balances at this level is seen in the Zambrano case where the government's initial draft legislative response to the decision was called out by an opinion produced by the Counsel of State for not complying with the decision, ${ }^{148}$ which meant that the legislature did not ultimately proceed with that part of the initial proposal. ${ }^{149}$ Accordingly, the CJEU was in effect able to keep the legislature in check by rendering its decision.

\section{The Desirability of Achieving Dialogue's Normative Claims at the International Level}

While it appears that the normative claims of dialogue are achieved in applying the dialogue model to the interactions between domestic legislatures and the European Courts, there remains a question as to whether this is in fact desirable.

The dialogue model produces a "better protection of rights," in part, because it facilitates a political protection of rights and thereby produces greater democratic deliberation. This is desirable. By giving a voice and role to the domestic legislature and by involving the voices of more and various stakeholders in the determination of rights issues, the public law dialogue model may go some way to addressing the criticism that international law itself, and, in particular, rights adjudication by international courts, is undemocratic. Benvenisti and Downs articulate this traditional criticism of international adjudication as follows:

[The] counter-majoritarian concern is exacerbated by decision-making by international institutions and tribunals, since they do not act "in the name of all the individuals whose lives they affect; and they do not ask for the kind of authorization by individuals that carries with it a responsibility to treat all those individuals in some sense equally." 150

\footnotetext{
${ }^{141}$ Benvenisti \& Downs, supra note 69 , at 69.

${ }^{142}$ Biao, App. No. 38590/10, at para. 61 .

${ }^{143} I d$. para. 49.

${ }^{144} I d$. para. 50

${ }^{145} I d$. para. 87.

${ }^{146}$ Zambrano, Case C-34/09 at 1233-34.

${ }^{147}$ Dixon, supra note 7 , at 413 .

${ }^{148}$ Opinion of the Conseil d'État, no 49 356/4 (4 April 2011) https://www.lachambre.be/FLWB/PDF/53/0443/53K0443015.pdf.

${ }^{149}$ See Baumgärtel \& Oomen, supra note 139 , at 40.

${ }^{150}$ Benvenisti \& Downs, supra note 75, at 179; Thomas Nagel, The Problem of Global Justice, 33 PHIL. \& PUBLIC AfFAIRs 113, 138 (2005). See also Schor, supra note 7, at 95; HiRSCHL, supra note 82.
} 
By the same token, applying the domestic dialogue model produces a "better protection of rights" by providing, in addition to a political protection of rights, a legal protection of rights. This outcome is desirable. By providing a voice and role to international courts, international law can govern, or at least influence in part, those rights areas traditionally in the purview of the political world and the state. The areas of membership and immigration are, for example, conventionally understood to fall almost exclusively within the state's sovereign prerogative. ${ }^{151}$ As demonstrated in Part $\mathrm{C}$ of this article, however, where state legislatures and the European Courts interact, the international courts are able to influence the state's understanding of these areas and provide some legal protection at the international level to non-nationals to enter and remain in a state. This enhances the credibility and authority of the international human rights legal system.

On another view, achieving public law dialogue's normative claims may not always be advantageous at the international level. At a fairly abstract level, an argument can be made that giving the state a voice and a role to play in human rights protection at the international level will inevitably fragment and undermine the universal application of international human rights law. Benvenisti argues, with respect to the margin of appreciation doctrine, for example, that yielding to the state's view on rights issues at all undermines the universal application of human rights, because it leads to "inconsistent applications in seemingly similar cases due to different margins." 152 This has implications for the enforcement of international human rights law. Benvenisti argues that giving a voice to states on rights issues, and the resulting fragmentation of international law, have the potential to "undermine seriously the promise of international enforcement of human rights." 153 Roach similarly questions whether entering into a dialogue on rights adjudication could mean that even those rights considered to be basic and core rights could be limited or not enforced. ${ }^{154}$ This in turn has implications for the legitimacy of the international human rights system more broadly and, as Benvenisti says, calls into question the "very authority of international human rights bodies to develop" international human rights standards. ${ }^{155}$

At a less abstract level, giving a voice to legislatures and states on rights protection could also leave the human rights of certain groups of people, such as minorities, vulnerable to abuse. Legislatures, as elected institutions can have, as Roach describes it, "an incentive to minimize and even trivialize the rights of the truly unpopular," 156 which results in the disenfranchisement of "discreet and insular minorities," such as "ethnic, cultural, religious, racial and national" minorities, by the political branch. ${ }^{157}$ Benvenisti suggests that "one of the main justifications for an international system for the protection of human rights lies in the opportunity it provides for promoting the interests of minorities" as the "system is an external device to ameliorate some of the deficiencies of the democratic system." ${ }^{158}$ Accordingly, where international courts, such as the European Courts, interact with domestic legislatures and allow the political branch what amounts almost to a partnership in rights protection, as the public law dialogue model proposes, some groups, such as minorities, whom international courts are meant to protect, could be left vulnerable. The interaction helps to ensure that the international law project is maintained and states are kept, in a sense, "on board" with the project. This is particularly important given that it is state parties that write and negotiate human rights treaties, and states can always withdraw

\footnotetext{
${ }^{151}$ See Walter Kälin, Aliens, Expulsion and Deportation, in MAX PlancK ENCYClOPEDia of International LAW 4 (2010).

${ }^{152}$ Benvenisti, supra note 110, at 843-44; Andrew LegG, The Margin of Appreciation In International Human Rights Deference And Proportionality 1 (2012).

${ }^{153}$ Benvenisti, supra note 110 , at 843 .

${ }^{154}$ Roach, supra note 46 , at 565.

${ }^{155} \mathrm{Id}$.

${ }^{156}$ Kent W. Roach, Sharpening the Dialogue Debate: the Next Decade of Scholarship, 45 OsGoode HaLL L. J. 169, 172 (2007).

${ }^{157}$ Eyal Benvenisti, The Margin of Appreciation, Subsidiarity and Global Challenges to Democracy, 9 J. INT. DisP. SETtLement 240, 241 (2018). Benvenisti also acknowledges that minorities can effectively engage in national politics and be "highly influential" in "outweighing diffuse majorities."

${ }^{158}$ Benvenisti, supra note 110 , at 850 . See also in Contreras, supra note 86, at 64-65.
} 
altogether from such treaties. But there is no doubt that the interaction, and the yielding to the political, does call the legitimacy of the system into question.

\section{Suggested Barriers to Dialogue at the International Level}

In light of this analysis, the article now considers whether some limitation can be placed on the application of the public law dialogue model to the interactions between domestic legislatures and the European Courts in such a way as to maximize the benefits of the model as set out above, but minimize potential weaknesses. Hogg and Bushell themselves acknowledged, with respect to the application of the dialogue model at the domestic level in the Canadian context, that there must be some "barriers to dialogue." They stated, "[w]hile it is generally the case that Charter decisions leave some options open to the competent legislative body, and allow a dialogue to take place between courts and legislatures, we must acknowledge that there may be some circumstances where the court will, by necessity, have the last word."159

As those dialogic mechanisms identified by Hogg and Bushell in the Canadian Charter provided a useful starting point for the application of the model to the interactions between domestic legislatures and the European Courts in Part C, two barriers suggested by Hogg and Bushell in the Canadian context also provide a useful starting point for considering how limitations to the application of the model might work here. ${ }^{160}$

Hogg and Bushell first argued that dialogue should not be engaged in with respect to those rights guaranteed in the Canadian Charter that "are framed in such specific terms that there is no room for Parliament or a provincial legislature to impose 'reasonable limits' on those rights." ${ }^{161}$ A similar barrier or limitation to dialogue might be useful here. That is, there should not be dialogue between state legislatures and international courts with respect to those rights set out in relevant conventions, or as understood at customary international law, that are in such specific terms that there is no room for their limitation. The right to be free from torture may be such a right, although the content of that right and the parameters of the meaning of "torture" are the subject of disagreement and controversy. This barrier to dialogue would, for example, address Roach's concerns set out above that the application of the dialogue model could cause even the guarantee of core or basic rights to be, in a sense, up for discussion.

There is some evidence that the ECtHR, at least, already ensures that, when it comes to such core rights, it retains the "last word" and does not enter into dialogue. The ECtHR, for example, applies proportionality tests to ensure that the core element of particular rights are not eroded, and it also appears to change the margin of appreciation that it affords to states depending on the particular right and breach in question. ${ }^{162}$ The Court in Evans v. United Kingdom held that:

Where a particularly important facet of an individual's existence or identity is at stake the margin allowed to the State will be restricted... Where, however, there is no consensus within the member States of the Council of Europe ... particularly where the case raises sensitive moral or ethical issues, the margin will be wider ....there will also usually be a wide margin if the State is required to strike a balance between competing private and public interests. ${ }^{163}$

\footnotetext{
${ }^{159}$ Hogg \& Bushell, supra note 7 , at 92 .

${ }^{160} I d$. at 95 . The third "barrier" identified by Hogg and Bushell was "where an issue is so controversial that it seems to preclude a legislative response to a judicial decision striking down a law for breach of the 'Charter."'

${ }^{161} I d$. at 92 .

${ }^{162}$ See, e.g., Obukhova v. Russia, App. No. 34736/03, para 22 (Jan. 8, 2009), https://hudoc.echr.coe.int/eng?i=001-90468; Czarnowski v. Poland, App. No. 28586/03, para. 32 (Jan. 20, 2009), https://hudoc.echr.coe.int/eng?i=001-90755; Lautsi v. Italy, App. No. 30814/06, para. 1 (Mar. 18, 2011) (Malinverni, J., dissenting) (quoting Buckley v. United Kingdom, 23 Eur. Ct. H.R. $101 \$ 74$ (1996), https://hudoc.echr.coe.int/eng?i=001-104040.

${ }^{163}$ Evans v United Kingdom, 46 Eur. Ct. H.R. 34, 77 (2008) [hereinafter Evans], https://hudoc.echr.coe.int/eng?i=00180046.
} 
This has resulted in the margin of appreciation doctrine usually being applied in decisions concerning the interpretation of Articles 8-11 and 14 of the ECHR, because these articles are those which are not textually entirely clear and the breach of which can be justified. ${ }^{164}$

Hogg and Bushell also suggested, in the Canadian context, that there be a barrier to dialogue "where the objective of the law is unconstitutional." 165 This barrier can be translated or analogized to some degree to the application of dialogue at the international level. That is, it might be appropriate not to have dialogue where the objective of a national law itself goes against the objectives of international law. As noted, one of the key justifications for international human rights law is that it provides protections for those not protected by, or at the margins of, the state. Accordingly, where a law involves the restriction of minority rights, this would be a circumstance where it could be appropriate for the international court to have "the last word." Benvenisti has argued, in the context of the margin of appreciation doctrine, that the doctrine should not be used to determine "conflicts between majorities and minorities," 166 and King points out, "even Ely's theory fully accepted that the court could intervene with hard remedies to protect minorities."167

The application of these "barriers" would address those criticisms or potential difficulties with the application of the dialogue model to the relationship between domestic legislatures and the European Courts and do so in such a way that would still enable the achievement of those normative claims that are desirable at the international level. Of course, in those areas where there is little, if any, international legal protection of rights, such as in the area of nationality and immigration, as were the examples used in this article, any potentially negative normative consequences for the application of the model and the relevant limitations to address those negative consequences, may not be relevant.

\section{E. Conclusion}

This article first demonstrated that the proposed application of the public law dialogue model here differs from those accounts of dialogue hitherto applied at the international and transnational level. The article then applied the model to the relationship between national legislatures and the ECtHR and between national legislatures and the CJEU and demonstrated that the public law dialogue model could provide an explanatory framework for the interactions between domestic legislatures and the European Courts. The article then contended that the normative claims of the dialogue model as it applies at public law translate across when it is applied in the proposed way. The article acknowledged that the achievement of those normative claims might not always be a desirable outcome, and accordingly, suggested that there be some limitations placed on the proposed application of the model to the interactions between domestic legislatures and the European Courts.

\footnotetext{
${ }^{164}$ Mónika Ambrus, The European Court of Human Rights and Standards of Proof: An Evidentiary Approach Towards the Margin of Appreciation, in Deference in International Courts and Tribunals: Standard of Review and Margin of APPRECiATiOn 235, 237 (Lukasz Gruszcynski \& Werner Wouter eds., 2014).

${ }^{165} \mathrm{Hogg}$ \& Bushell, supra note 7, at 93-94.

${ }^{166}$ Benvenisti, supra note 110 , at 847.

${ }^{167} \mathrm{King}$, supra note 26 , at 199.
}

Cite this article: Gillis M (2022). Can We Talk? The Application of the Public Law Democratic Dialogue Model to the Interactions between Domestic Legislatures and the European Courts. German Law Journal 23, 56-78. https://doi.org/ $10.1017 /$ glj.2022.6 